\title{
Stigmatization, Discrimination, Racism, Injustice, and Inequalities in the COVID-19 Era
}

\author{
Jaime A. Teixeira da Silva*
}

\begin{abstract}
*Correspondence to: Jaime A. Teixeira da Silva, Email: jaimetex@yahoo.com Copyright: ( 2020 The Author(s); Published by Kerman University of Medical Sciences. This is an open-access article distributed under the terms of the Creative Commons Attribution License (http://creativecommons.org/licenses/ by/4.0), which permits unrestricted use, distribution, and reproduction in any medium, provided the original work is properly cited.

Citation: Teixeira da Silva JA. Stigmatization, discrimination, racism, injustice, and inequalities in the COVID-19 era. Int J Health Policy Manag. 2020;9(11):484-485. doi:10.34172/ijhpm.2020.87

Received: 20 May 2020; Accepted: 31 May 2020; ePublished: 3 June 2020
\end{abstract}

\section{Dear Editor,}

The pandemic caused by the severe acute respiratory syndrome coronavirus 2 (SARS-CoV-2), which induces the respiratory coronavirus disease 2019 (COVID-19) and has transformed society, medicine, and values in so many ways, has already claimed (May 31, 2020) 369627 lives and infected 6087902 people globally. ${ }^{1}$ During this highly transformative period, human interactions have been forcefully altered, either through implemented social distancing or lockdowns, to limit the spread of the virus. Reducing people's movement, and the duration and frequency of contact between them, imposes artificial barriers of contact that can lead to friction and discord. Healthcare systems, often under pressure, were unprepared and faced life-and-death decisions, reigniting or amplifying sensitive social issues, including stigmatization, discrimination, racism, injustice, and inequalities, as a result of health disparities. ${ }^{2}$

In this time of isolation, affected individuals have largely stayed in contact through social media and online apps, but the use of social media has also seen a rise in misinformation ${ }^{3}$ and fake news, ${ }^{4}$ which may negatively impact the health and lives of individuals, especially those seeking advice regarding sanitary conditions or treatments to halt or prevent COVID-19. Compounding the immediacy of the pandemic, patients infected by this virus may be receiving prioritized treatment at the expense of patients with other critical illnesses. ${ }^{5}$ The strain on human resources, particularly healthcare workers, is acute when essential care and equipment becomes scarce, leading to competition between critical care and emergency cases, or even negligence of the elderly, those with special disabilities, as well as indigenous, homeless, migrant and imprisoned populations. ${ }^{6}$ Border closure, limiting the international or transnational movement of individuals, or imposed travel restrictions, worsened the plight of asylum seekers and undocumented migrants. ${ }^{7}$ These travel restrictions might be a violation of International Health Regulations if the restriction infringes upon rights of movement to seek a better or viable health solution. ${ }^{8}$

There was a rise in anti-Chinese sentiment, or racism, causing shame and stress to Chinese nationals or even to other Asians, and thus stigmatization. ${ }^{9}$ Such prejudice often arises with the need for self-protection, and the fear underlying this need for a racialized response to the COVID-19 threat led to some panic and hysteria, microaggressions and mass generalizations, even spates of violence and protests, causing the disproportional victimization of ethnic minorities and socio-economic discrimination of marginalized groups, made worse by erroneous misinformation..$^{10}$

Curtailed movement and choices, or intrusive and forcefully imposed policies, restrictions or regulations, the use of state surveillance, drones, forced implementation of mobile apps to track citizens and the spread of COVID-19, color coding for citizens based on their travel and health status, as well as profiling, even under the premise of protecting society's health, may be used to fortify state control and surveillance, possibly restricting civil liberties, or freedoms and rights, thereby raising privacy concerns by suspending democratic deliberation or fortifying authoritarianism. ${ }^{11,12}$ COVID-19 might fortify other psychosocial and structural burdens, including misogyny, homophobia, homelessness and mental health. ${ }^{13}$

In this pandemic, and in post-COVID-19 societies, the challenges that humanity faces as a result of limitations need to be addressed now, prior to the arrival of the next pandemic, or the resurgence of this one. If the healthy versus sick dividing line can be better appreciated through solid scienceand evidence-based medicine, and if proper public health governance and policies can be effectively implemented through resolute political leadership, then more compassion towards those infected by COVID-19, or respect towards others that are mistreated as a result of this pandemic, including those who recovered from COVID-19 and are living a post-infection life, may emerge and prevail..$^{14,15}$

Ethical issues Not applicable. 


\section{Competing interests}

Author declares that he has no competing interests.

Author's contribution

JATdS is the single author of the paper.

\section{References}

1. John Hopkins University. Coronavirus Resource Center. https:// coronavirus.jhu.edu/map.html. Accessed May 31, 2020.

2. van Dorn A, Cooney RE, Sabin ML. COVID-19 exacerbating inequalities in the US. Lancet 2020;395(10232):1243-1244. doi:10.1016/S0140-6736(20)30893-X

3. Ren SY, Gao RD, Chen YL. Fear can be more harmful than the severe acute respiratory syndrome coronavirus 2 in controlling the corona virus disease 2019 epidemic. World J Clin Cases 2020;8(4):652-657. doi:10.12998/wjcc.v8.i4.652

4. Shimizu K. 2019-nCoV, fake news, and racism. Lancet 2020;395(10225):685-686. doi:10.1016/S0140-6736(20)30357-3

5. Baker T, Schell CO, Petersen DB, et al. Essential care of critical illness must not be forgotten in the COVID-19 pandemic. Lancet 2020;395(10232):1253-1254. doi:10.1016/S0140-6736(20)30793-5

6. Vieira CM, Franco OH, Restrepo CG, Abel T. COVID-19: The forgotten priorities of the pandemic. Maturitas 2020;136:38-41. doi:10.1016/j.maturitas.2020.04.004

7. Orcutt M, Patel P, Burns R, et al. Global call to action for inclusion of migrants and refugees in the COVID-19 response. Lancet 2020; In Press. doi:10.1016/S0140-6736(20)30971-5
8. Habibi R, Burci GL, de Campos TC, et al. Do not violate the International Health Regulations during the COVID-19 outbreak. Lancet 2020;395(10225):664-666. doi:10.1016/S01406736(20)30373-1

9. Chung RY, Li MM. Anti-Chinese sentiment during the 2019-nCoV outbreak. Lancet 2020;395(10225):686-687. doi:10.1016/S01406736(20)30358-5

10. Devakumar D, Shannon G, Bhopal SS, Abubakar I. Racism and discrimination in COVID-19 responses. Lancet 2020;395(10231):1194. doi:10.1016/S0140-6736(20)30792-3

11. Studdert DM, Hall MA. Disease control, civil liberties, and mass testing - calibrating restrictions during the Covid-19 pandemic. New England J Med. 2020; In Press. doi:10.1056/NEJMp2007637

12. Ang YY. When COVID-19 meets centralized, personalized power. Nature Human Beh. 2020;4(5):445-447. doi:10.1038/s41562-0200872-3

13. Shiau S, Krause KD, Valera P, et al. The burden of COVID-19 in people living with HIV: a syndemic perspective. AIDS Behav. 2020; In Press. doi:10.1007/s10461-020-02871-9

14. Logie $\mathrm{CH}$, Turan JM. How do we balance tensions between COVID-19 public health responses and stigma mitigation? Learning from HIV research. AIDS Behav. 2020; In Press. doi:10.1007/ s10461-020-02856-8

15. Smith GD, Ng F, Li WHC. COVID-19: Emerging compassion, courage and resilience in the face of misinformation and adversity. J Clin Nursing 2020;29(9-10):1425-1428. doi:10.1111/jocn.15231 